\title{
ALGUNS CAMINS PER A APAIVAGAR ELS CONFLICTES PER INCIDENTS DE PIRATERIA EN EL MEDITERRANI OCCIDENTAL ${ }^{1}$
}

\author{
WAYS TO BRING ABOUT PEACE IN CONFLICTS ARISING OUT \\ OF INCIDENTS OF PIRACY \\ IN THE WESTERN MEDITERRANEAN
}

\author{
JOSEFINA MUTGÉ I VIVES \\ Institució Milà i Fontanals, \\ CSIC. Barcelona
}

\begin{abstract}
Resum: Aquest treball té com a finalitat estudiar els diferents sistemes utilitzats en els segles XIII i XIV pels sobirans catalanoaragonesos per tal d'evitar el desencadenament de les temudes cartes de marca o de represalia que els governs de les nacions concedien a un dels seus súbdits per a confiscar els béns dels ciutadans de l'estat estranger del qual havia sofert un greuge. Els sobirans catalanoaragonesos tractaren d'impedir que les marques que els rei de França decretaren contra la Corona d'Aragó fossin evitades. Per això utilitzaren tres vies: 1 . Les negociacions diplomàtiques amb la cort francesa. 2. La instauració d'un impost sobre les mercaderies, amb la recaptació del qual poder compensar els perjudicats. 3. La indemnització dels perjudicats utilitzant els recursos de la propia Corona catalanoaragonesa.
\end{abstract}

Paraules clau: Piratería; Cartes de marca o represalia; Negociacions diplomàtiques; Impostos; Relacions França-Corona d'Aragó; Segles XIII-XIV.

\begin{abstract}
This paper has as its aim the study of the different systems used in the XIII and XIV centuries by the CatalanoAragonese sovereigns to avoid the dreaded letters of warrant or reprisal issued by the governments of various nations. These were granted to one of their subjects to allow him to confiscate property belonging to the citizens from the foreign state which had suffered the wrong. The CatalanoAragonese sovereigns tried to avoid the letters of warrant decreed against the Crown of Aragon by the kings of France. They used three ways to achieve this: 1 . By diplomatic negotiations with the French Court. 2. By the institution of a tax on the merchandise, with which they could compensate those who had been wronged. 3 . By the indemnification of the person wronged through the recourses available to the Catalano-Aragonese crown itself.
\end{abstract}

Keywords: Piracy; Letters of warrant or reprisal; Diplomatic negotiations; Taxes; Relations between France and the Crown of Aragon; $13^{\text {th }}$ and $14^{\text {th }}$ centuries.

${ }^{1}$ El present estudi s'insereix dins del Projecte d'Investigació “La Corona de Aragón en el Mediterráneo medieval: puente entre culturạs mediaḍora entre Crịstiandad e Islam" (Ref. HUM2007-61131), subvencionat pel Ministeri de Ciència i Innovació i dirigit per la Dra. Roser Salicrú i Lluch. També forma part de l'Ajut de la Direcció General de Recerca de la Generalitat de Catalunya, a través del Grup Consolidat "La Corona catalanoaragonesa, l'Islam i el Món mediterrani" (Ref. 2005 SGR00193), dirigit per la Prof a Dra. Maria Teresa Ferrer i Mallol.

Les abreviatures utilitzades són les següents: ACA = Arxiu de la Corona d'Aragó; AHCB = Arxiu Històric de la Ciutat de Barcelona; $\mathrm{C}=$ Cancelleria; $\mathrm{CC}=$ Secció Consell de Cent; $\mathrm{CR}$ = Cartes reials; fol., fols. = foli, folis; Ll. C. = Llibre del Consell de la Ciutat de Barcelona; p., pp. = pàgina, pàgines; reg. = registre; r. = recto; v. = verso. 


\section{SUMARI}

1. Les negociacions.- 2. Instauració d'un impost.- 3. Indemnització per la Corona.

És un fet ben conegut que els freqüents atacs de pirates i corsaris que es produïen en el mar foren les causes que més varen pertorbar el normal desenvolupament del comerç a la Mediterrània durant l'Edat Mitjana. S'ha escrit molt i s'ha debatut molt sobre la pirateria i el cors i sobre les diferències entre l'una i l'altra pràctica. Recentment, s'ha publicat un estudi molt complet sobre aquesta qüestió de la pirateria i del corsarisme ${ }^{2}$, i a aquest estudi remetem el lector, on hi trobarà també tota la bibliografia publicada i l'estat de la qüestió sobre el tema.

Aquí no tractarem dels actes de pirateria i de les seves conseqüències que, com dic, ja han estat estudiats abastament, sinó que més aviat ens fixarem en els sistemes que s'utilitzaven, a fi que els perjudicats per un acte d'aquesta mena recuperessin allò que els havia estat injustament robat.

En els segles XIII i XIV la manera més fàcil i més utilitzada perquè els perjudicats es rescabalessin dels danys soferts era la concessió de les anomenades cartes de marca o represàlia. El dret de marca era el que el govern d'una nació concedia a un dels seus súbdits, mitjançant el qual podia confiscar els béns dels ciutadans de l'estat estranger del qual havia sofert un greuge i no havia pogut obtenir la satisfacció que li era deguda per les vies judicials del país del seu adversari ${ }^{3}$.

Es va posar en pràctica aquell principi "del mal el menys". Així, qualsevol que es considerés perjudicat podia rescabalar-se dels danys soferts robant l'agressor, si el podia trobar i, si no, ho feia a costa dels presumptes còmplices de l'agressor: parents, amics, aliats, conciutadans, compatriotes, etc., en virtut del principi de la responsabilitat col-lectiva. El procés que es seguia era el següent: en primer lloc, s'havia d'haver produït un dany real causat per una escomesa violenta; aquest dany es denunciava a l'autoritat

${ }^{2}$ És el documentat treball de Maria Teresa FERRER I MALLOL, Corso y piratería entre Mediterráneo y Atlántico en la Baja Edad Media, dins La Península Ibérica entre el Mediterráneo
y el Atlántico. Siglos XIII-XV (Cádiz, 1-4 de abril de 2003). Manuel GoNZÁLEZ JIMÉNEZ; Isabel MONTES ROMERO-CAMACHO, editores, Sevilla-Cádiz, 2006, pp. 255-322.

${ }^{3}$ Sobre les marques, es pot consultar: René de MAS LATRIE, Du droit de marque ou droit de représailles au Moyen Age, París, 1875, 123 pp. (Bibliothèque de l'Ecole des Chartes, $\mathrm{VI}^{\mathrm{e}}$ série, t. II); A. DEL VECCHIO, ed. E. CASANOVA, Le rappresaglie nei comuni medievali e spezialmente in Firenze, Bologna, 1894. Ristampa anastatica, Bologna, 1974; J. EIGLIER, Etude historique sur le droit de marque ou de représailles à Marseille aux XIIIe. XIVe et XVe siècless. Marseille, 1885; Joaquim MIRET I SANS, Les represàlies a Catalunya durant l'Edat Mitjana. Extret de la "Revista Jurídica de Catalunya", Barcelona, 1925; André HAUMANT, Les représailles, París, 1934; Ruy de ALBUROUERQUE, As represálias. Estudo de História do Direito português (secs. XV e XVI), Lisboa, 1972; Antonio de CAPMANY Y DE MonPALAU, Memorias historicas de la marina, comercio y artes de la antigua ciudad de Barcelona, 4 vols., Madrid, 1792. Reedición anotada, 3 vols., Barcelona, 1961-1963. 
competent de la que depenia el delinqüent per a que fos reparat ${ }^{4}$. Si no es feia la satisfacció corresponent, es concedia una carta de marca al perjudicat perquè es rescabalés de les pèrdues a costa dels conciutadans de l'agressor. En poques paraules: la condició essencial - excepció feta d'un estat de guerra declarada- era la negació de justícia. Certament, els actes de pirateria eren molt freqüents, però les cartes de represàlia també es concedien sense límit ni control. A més, molt sovint, es produïa una sobrevaloració dels danys soferts. L'esperit de venjança i l'afany d'obtenir un benefici convertien la víctima d'una agressió en un pirata més, quan es veia en possessió d'una carta de marca. En el segle XIV, les represàlies foren tan freqüents i portaven tanta inseguretat en el mar i tanta pertorbació al normal desenvolupament del comerç com els mateixos atacs dels pirates, per això, calia que se'n reglamentés la concessió i així, poc a poc, se'n va anar restringint el seu ús a certs casos i sota determinades condicions. Els governs, per via diplomàtica, començaren a posar limitacions a la concessió indiscriminada de marques ${ }^{5}$. Per exemple, el 27 d'abril de 1313, el monarca francès Felip IV el Bell i el català Jaume II signaren un conveni, segons el qual, en endavant, no podria concedir-se cap marca entre ambdues nacions pel mer fet d'una denegació de reclamacions, sinó que la concessió havia d'anar precedida d'un llarg procés que durava prop d'un any ${ }^{6}$.

Es donava moltes vegades la circumstància que els sobirans de dos estats, malgrat estar en bones relacions polítiques entre ells, concedien cartes de marca als seus súbdits contra els de l'altra nació.

El que comentarem aquí son les diverses vies que els reis o els governants de les ciutats utilitzaven per tal d'evitar l'execució de les cartes de marca i tractar de compensar els perjudicats per l'agressió piràtica soferta per altres mitjans. Farem una anàlisi o nova lectura de diversos casos estudiats per nosaltres en diverses ocasions. Com es pot comprendre, tot això produïa unes negociacions que, per força, es reflectien en les cancelleries reials o municipals.

\section{LES NEGOCIACIONS}

El mitjà més immediat per a compensar els damnificats per roberies i evitar que es posessin en pràctica les temudes cartes de marca era la via de composició o acord, mitjançant negociacions diplomàtiques.

\footnotetext{
${ }^{4}$ Michel Mollat fa un estudi de tots els extrems que s'havien de tenir en compte a l'hora de denunciar una agressió piràtica (M. MOLLAT, Essal d'orientation pour l'étude de la guerre de course et la piraterie . XIII'-XV siècles, "Anuario de Estudios Medievales", 10 [1980], pp. 743749).

${ }^{5}$ A. de Capmany, Memorias, cit. I, p. 401 (citem per la reedició); J. Miret i Sans, Les represălies, cit. p. 53 .

${ }^{6}$ A. de CAPMAnY, Memorias, cit., I, pp. 401-402; II, doc. 137, p. 206 i ss. J. Miret I SANS, Les represălies, cit. p. 54 i nota 1.
} 
Comentarem un cas o exemple en el qual els danys derivats d'una agressió piràtica es van intentar resoldre amb una avinença. Ens referim a la que es va produir l'any $1319^{7}$. Les víctimes d'aquesta agressió foren uns mercaders catalans que havien sortit de Trapani (Sicília) i navegaven cap a Barcelona, repartits en dues coques i els atacants foren castellans de Sevilla ${ }^{8}$. Quan les dues coques de catalans es trobaren prop de Sardenya varen ser atacades per les coques de castellans, sense que aquests tinguessin en compte la situació de treva existent llavors entre els reis de Castella i d'Aragó, després del fracàs de la campanya d'Almeria contra els musulmans i de la política matrimonial intentada per Jaume II $^{9}$; així doncs, en aquest temps de treva, en el qual Jaume II havia abandonat els afers castellans i començava a preparar la conquesta de Sardenya va ser quan es va produir aquesta escomesa. Els pirates sevillans després de robar als mercaders catalans tot el que portaven, se'ls endugueren presos i els retingueren durant sis dies, causant-los greus perjudicis. Com era costum en casos semblants, per ordre del rei, es va fer una relació fidedigna dels esdeveniments i una estimació dels béns robats ${ }^{10}$.

En aquest cas, com que les coques atacants havien estat armades a Sevilla, els consellers de Barcelona, el 19 de desembre de 1319, varen començar a negociar amb el govern municipal de Sevilla i amb l'almirall major del rei de Castella, Alfonso Jofre, i els demanaren que, tenint en compte la pau que hi havia entre els reis de Castella i de Catalunya-Aragó i l'amistat entre els governs municipals de Barcelona i de Sevilla, procuressin que les mercaderies o el valor d'aquestes, juntament amb les despeses esmerçades en la seva recuperació, danys i interessos fossin restituïts als mercaders catalans o al seu procurador Jaume Colliure, el qual fou designat per a dur a terme les gestions encaminades a recobrar tot allò que havia estat

\footnotetext{
${ }^{7}$ Vegeu la descripció i detalls d'aquest assalt piràtic a J. MuTGÉ, Activitat piràtica entre catalano-aragonesos i castellans a la Mediterrània Occidental durant el regnat de Jaume II, "Congrés Internacional Jaume II, set-cents anys després" "Anales de la Universidad de Alicante", 11 (1996-1997), pp. 445-453. Aquests assalts piràtics es troben enregistrats a l'AHCB, CC' Ll.C., vol. 5 , fols. 54 v. i ss. i vol 6 , fols. 24 v. i ss.

${ }^{8}$ Els mercaders barcelonins eren G. Ferran, Bernat Sestany, P. Percàç, Jaume Samenla, Jaume Colliure, Simó Xifre, Jaume Conill, Joan Batlle; i els patrons dels vaixells P. Sabater, Francesc Desvalls i Jaume Conill. Els patrons de les coques agressores eren Pascual Mandeta de Castro i Juan Gonzálvez de Santander (Cf. J. Mutgé, Activitat piràtica, cit., p. 448).

${ }^{9}$ Sobre la campanya d'Almeria, vegeu A. GIMÉnEZ SOLER, El sitio de Almería en 1309 , Barcelona, 1904, 113 pp.; IDEM, La Corona de Aragón y Granada, "Boletín de la Real Academia de Buenas Letras de Barcelona", 3 (1905-1906), pp. 342-343; M.T. FERRER I MALLOL, La frontera amb l'Islam en el segle XIV. Cristians i sarraïns al País Valencia, Barcelona, 1988, pp. 99-101. Quant al fracàs de la política matrimonial de Jaume II respecte a Castella, cal recordar que Pere de Castella, marit de la infanta Maria, filla de Jaume II, va morir lluitant contra els musulmans el juliol de 1319 (Cf. A. GIMÉNEZ SolLER, La Corona de Aragón y Granada, pp. 7980; M.T. FERRER I MALLOL, La frontera amb l'Islam, pp. 117 i ss.).

${ }^{10} \mathrm{El}$ total de productes robats fou el següent: 23 persones, entre musulmans i musulmanes, tres captives gregues; 22 sacs de bescuit (un pa cuit dues vegades per tal que s'assequés i durés molt de temps. Era utilitzat per a proveir les barques i les armades); formatges; un guant de ferro (que devia formar part d'una armadura); sis gerres de tonyina; cinc botes de vi; els fou exigit el lliurament de 12 dobles d'or o el seu equivalent en monedes d'or i de plata. Tot això atenyia la suma de 19.547 sous barcelonesos $\mathrm{i} 12$ dobles d'or. (AHCB, CC, Ll. C. 5 , fols. 54 v. -55 v. vol. 6, fols. 24 v.-25 v. Cf. J. MuTGÉ, Activitat piràtica, cit., pp. 448-449),
} 
confiscat ${ }^{11}$. L'activitat diplomàtica desplegada pels consellers de Barcelona no acabà aquí, sinó que també recorregueren a l'arquebisbe de Sevilla, Fernando Tello $^{12}, \mathrm{i}$ als cònsols de catalans perquè, per aquests anys, Barcelona ja tenia consolat a Sevilla, el qual depenia directament del govern municipal de Barcelona, i una de les principals obligacions dels cònsols era la d'ajudar i defensar els mercaders catalans, especialment els barcelonins, i les seves mercaderies $^{13}$. No només els consellers de Barcelona desplegaren la seva diplomàcia sinó que també el rei Jaume II s'interessà especialment en aquest succés de roberia manifesta, mal exemple i pèrdua per als barcelonins i va demanar al rei de Castella, a l'almirall major, Alfonso Jofre, i al govern municipal de Sevilla que els danys fossin restituïts ${ }^{14}$. Sembla que no s'obtingué cap resultat d'aquestes gestions. En aquestes situacions, es recorria a una altra arma pacífica consistent a alertar tots aquells qui habitaven les costes de la Mediterrània occidental i als cònsols de catalans de la presència de vaixells pirates, per tal que es prenguessin les màximes precaucions i les mesures defensives pertinents. Això és el que van fer els consellers de Barcelona després d'aquest assalt i davant del creixent rumor que a Sevilla s'armaven coques i galeres destinades a atacar els súbdits del rei catalanoaragonès i els del rei de Sicília. Concretament, a la darreria de l'any 1319, el govern barceloní advertia el rei Frederic de Sicília del perill que corria a causa d'aquests pirates castellans i li demanava que posés tots els mitjans per a guardar-se'n. Li demanaven que, si aquestes coques i galeres atenyessin les mars de Sicília, els tinguessin com a malfactors ${ }^{15}$. Així mateix, els consellers de Barcelona es varen adreçar a l'infant Alfons, fill de Jaume II, hereter de la Corona i procurador general del rei, a fi que ell, pel seu compte, també advertís el rei Frederic de Sicília del greu perill que representaven els pirates sevillans i que aquest darrer, al seu torn, fes arribar aquest avís al castellà de Malta. Els consellers barcelonins demanaven també a l'infant Alfons que manés al veguer de Barcelona que instituís una taxa, a càrrec dels mercaders de Barcelona, per tal de contribuir, entre tots, a pagar les despeses ocasionades per la barca i pel lleny armats que navegaven per la Mediterrània occidental avisant els vaixells catalanoaragonesos de guardar-se dels vaixells

${ }^{11}$ AHCB, CC, Ll. C., 5, fols. 54 v.-55 r. J. MuTGÉ, Activitat piràtica, cit., p. 449.

${ }^{12} \mathrm{AHCB}$, CC, Ll. C. , 5, fol. 51 r.; i 6, fols. 25 v.-26 r. (1319, desembre, 19). J. MutGÉ, Activitat piràtica, cit.,p. 450 .

${ }^{13} \mathrm{AHCB}, \mathrm{CC}$, Ll. C., 5, f. 55v.; 6, f. 26 r. (1319, desembre, 19). J. MuTGÉ, Activitat piràtica, cit., p. 450; EADEM, Projecció de Barcelona en l'ámbit peninsular: notícies sobre el consolat de catalans a Sevilla, 1282-1327, dins El municipi de Barcelona i els combats pel govern de la ciutat, J. ROCA I ALBERT, coord., Ajuntament de Barcelona i Edicions Proa, 1997, pp. 2938 .

${ }^{14}$ Sobre l'almirallat, vegeu F. PÉREZ EMBID, El almirantazgo de Castilla hasta las capitulaciones de Santa Fe, Sevilla, 1944 pp. 114-122; M. GARCÍA FERNÁNDEZ, El reino de
Castilla en tiempos de Alfonso XI (1321-1350), Sevilla, 1989, p. 277 .

15 "tamquam raptores et malefactores capi faciatis cum ipsos vere raptores et malefactores sentierimus anno proxime preterito" (AHCB, CC, Ll. C., 5, ff. 66 r.-67 v. J. MUTGE, Activitat piràtica, p. 451). 
castellans. Aquesta taxa seria fixada per mercaders bons i honrats de la ciutat de Barcelona ${ }^{16}$.

\section{LA INSTAURACIÓ D’UN IMPOST}

Un sistema utilitzat per a compensar els perjudicats per roberies va ser la instauració d'un impost. Així es va fer en l'acte de pirateria perpetrat sobre la coca del mercader barceloní Esteve Bordell, un cas ben conegut que també generà una gran activitat diplomàtica i, per consegüent, molta documentació. El fet tingué lloc durant el regnat de Jaume II, concretament l'any $1322^{17}$. En aquesta ocasió, els atacants varen ser genovesos. Val a dir que la pirateria recíproca catalanogenovesa era una constant a la Mediterrània en aquells anys. La causa s'ha de cercar en l'expansió que la Corona d'Aragó i Barcelona havien assolit en els darrers temps del regnat de Jaume II, la qual, forçosament, havia de comportar un enfrontament amb una altra potència marítima, la república de Gènova. Els genovesos que sempre havien estat enemics de tots aquells que els poguessin fer la competència en la pràctica del comerç, necessàriament ho havien de ser dels catalans, als quals trobaven presents a tots els mercats mediterranis. La concurrència als mateixos mercats, idèntics interessos i els mateixos afanys imperialistes dels uns i dels altres expliquen aquesta rivalitat que duraria segles. L'ocupació de Sicília per la Corona d'Aragó, sens dubte, ja va incrementar aquesta rivalitat, que encara augmentaria més amb la conquesta de Sardenya ${ }^{18}$. L'atac a la coca d'Esteve Bordell es va produir en el mes d'agost de l'any 1322, abans, per tant, de la conquesta de Sardenya, quan Esteve Bordell venia de Xipre, on havia carregat una coca de la seva propietat amb moltes i diverses mercaderies, el preu de les quals sobrepassava les 150.000 lliures barceloneses i les portava amb destinació a Barcelona. Quan Esteve Bordell, es trobava a les mars de Sicília, davant del cap de Tre Fontane (situat a la província de Trapani, prop de la localitat de Campobello di Mazzara), els va sortir del port de Trapani una coca de genovesos de Savona, els quals pertanyien a la facció dels gibel·lins; atacaren la coca d'Esteve Bordell, a qui varen matar, feriren d'altres tripulants, prengueren violentament la coca amb totes les mercaderies que portava i se la varen endur ${ }^{19}$.

\footnotetext{
${ }^{16}$ AHCB, CC, Ll. C., 5, fol. 68 r. (1319). Cf. J. MuTGÉ, Activitat piràtica, pp. 451-452.

${ }^{17}$ Sobre l'atac piràtic a Esteve Bordell vegeu J. MuTGÉ, Contribució a l'estudi del comerç al Mediterrani Occidental en el segle XIV: l'atac piràtic a la coca d'Esteve Bordell, "Anuario de Estudios Medievales", 24 (1994), pp. 465-477. La font documental en la qual es descriu l'assalt que va sofrir Esteve Bordell es troba a AHCB, CC, Ll. C., vol. 7, fols. 61 v.-64 v.

${ }^{18} \mathrm{Cf}$. Vicente SALAVERT, El problema estratégico del Mediterráneo occidental y la política aragonesa , siglos XIV y XV), "Actas y comunicaciones del IV Congreso de Historia de la Corona de Aragón", P, Palma de Mallorca, 1955, pp. 201-206; Marina MITJÀ, Barcelona y el problema sardo en el siglo XIV, "VI Congreso de Historia de la Corona de Aragón", Cerdeña, 1957, pp.
$447-450$.

${ }^{19} \mathrm{AHCB}, \mathrm{CC}, \mathrm{Ll} . \mathrm{C} ., \mathrm{7}$, fols. 61 v.-64 v.
} 
Aquesta agressió fou considerada pel Consell municipal de Barcelona com un greu deshonor per al rei catalanoaragonès Jaume II i un important perjudici econòmic per a la ciutat de Barcelona i per als seus habitants. Tot seguit, ja es va iniciar tot el llarg procés de negociacions encaminades a recuperar els béns robats. En aquest cas, com que el fet es va produir en els mars de Sicília, dintre dels dominis del rei Frederic, el 22 d'octubre de 1322, els consellers de Barcelona no dubtaren a recórrer a ell, tot al·legant la concòrdia existent entre ambdós. Li feien avinent que, en consideració a aquesta bona amistat, forçosament havia de desagradar-li que els genovesos o tots altres que anessin a avituallar-se a les seves terres causessin danys als súbdits del rei de la Corona d'Aragó, germà seu, i als barcelonins, així mateix amics seus. En un principi, els consellers de Barcelona, per tal de recuperar els béns perduts, volien utilitzar el dret de marca ja que demanaven al rei Frederic que, en el cas que els genovesos demoressin la restitució dels danys causats als catalans, ordenés que tots els compatriotes d'aquells qui circulessin per les demarcacions sicilianes fossin obligats a fer algun pagament per a ajudar a la recuperació dels danys i perjudicis. Allò que els consellers demanaven a Frederic de Sicília no era altra cosa que la concessió del dret de marca o represàlia. També s'adreçaren, en demanda de col·laboració, a Carles VI el Bell, rei de França, al senescal de Bellcaire (Beaucaire) i al veguer d'Aigüesmortes. El 3 de novembre de l'esmentat any de 1322, els magistrats barcelonins varen trametre Guillem Oliver i Bernat de Montalegre, mercaders i ciutadans de Barcelona, a França, per tal de fer les gestions pertinents. Aquests personatges, a més de tractar de l'atac sofert per Esteve Bordell, tenien ordres de confiscar les mercaderies d'una coca que, segons es deia, procedent de Romània, es dirigia al port d'Aigüesmortes ${ }^{20}$. Veiem doncs com, de primer antuvi, els consellers volien obtenir un dret de marca per a rescabalar-se de les pèrdues ocasionades en la roberia a Esteve Bordell. Tanmateix, a partir de l'any 1325 , es produí la intervenció de Jaume II i, en el mes de juny del dit any, ja es van iniciar les negociacions diplomàtiques per a arribar a un acord o avinença entre el monarca catalanoaragonès, la ciutat de Barcelona i els qui havien resultat perjudicats per la captura de la coca d'en Bordell, de l'una banda, i els genovesos, de l'altra. El procés seguit per a arribar a aquesta avinença es coneix gràcies a les actes notarials enregistrades a la sèrie denominada Manual del Consell de Cent, conservada a l'Arxiu Històric de la ciutat de Barcelona ${ }^{21}$. Cal tenir present que, en l'atac a la coca d'Esteve Bordell, hi participaren totes dues faccions dels genovesos, tant els gibel-lins de Savona com els güelfs de Génova. A partir del març de 1325, els consellers varen fer els possibles per a negociar amb els de Savona els quals, a l'estiu del dit any, s'avingueren a anar pagant determinades quantitats que es descomptarien de l'import total pel qual era valorada la roberia. Es donà la circumstància que, pels mateixos dies, el Comú de Génova havia tramès

\footnotetext{
${ }^{20} \mathrm{AHCB}, \mathrm{CC}$, L1. C., 7, fol. 64 r.-v. Cf. J. MuTGÉ, Contribució a l'estudi, cit., pp. 468-469.

${ }^{21}$ AHCB, CC, Sèrie XIII: Manual del Consell de Cent, vol. I, fols. 24 r. i ss. Cf. J. MutGÉ, Contribució a l'estudi, pp. 469-470.
} 
ambaixadors a Jaume II per a tractar de la repetida restitució de la coca d'en Bordell. Per consegüent, a la reunió del Consell de Cent de Barcelona, celebrada el 27 de juliol de 1325, es varen designar els ciutadans barcelonins Bernat de Marimon i Burguet de Sarrià, jurisperits, i el mercader Bernat Mascarell perquè actuessin en nom del rei i de la ciutat comtal. Com a resultat d'això, abans del final de l'estiu de 1325, efectuades les negociacions, els genovesos es comprometeren a arranjar la següent composició: pagarien 62.061 perpres d'or a Pera, a Romania; 6.465 lliures genoveses a Savona; i 74.000 lliures barceloneses, les quals s'obtindrien d'un impost o gabella que seria exigida a l'esmentada ciutat de Savona, consistent a pagar 4 sous per cada mina de sal. També abonarien 2.700 perpres d'or, en compensació de la coca $\mathrm{i}$ de les eixàrcies que hi havia en aquesta ${ }^{22}$.

Val a dir que la pràctica d'intentar compensar els afectats per un assalt piràtic mitjançant la instauració d'un impost i evitar així les marques, ja era coneguda i practicada. Sabem que l'any 1218, entre les ciutats italianes de Florència i Peruggia es va pactar que, per evitar les marques i poder indemnitzar pacíficament els perjudicats per roberies i per altres greuges ocasionats pels naturals d'una república als de l'altra, s'instituís un impost o dret a pagar sobre les mercaderies que entressin o sortissin recíprocament, de llurs territoris ${ }^{23}$. Per aquest camí també anava l'anomenat Lou dels Pisans, és a dir, el laudum o acord signat el 24 de novembre de 1303 entre Jaume II de Mallorca i el Comú de Pisa, a fi que, per tal que els mallorquins poguessin ésser rescabalats dels danys causats pels pisans, aquests haurien de pagar un impost sobre totes les mercaderies que introduïssin o traguessin del regne de Mallorca ${ }^{24}$.

A partir de la tardor de l'any 1325, per part de la Corona catalanoaragonesa, i especialment de Barcelona, començaren les gestions i missatgeries a fi de cobrar les expressades quantitats, i es tingué bona cura de fixar unes condicions per a efectuar amb seguretat el viatge a la Mediterrània Oriental, com també les despeses que això comportava, fins al punt que es va decretar el pagament d'una talla entre els afectats per la roberia per tal de reintegrar als missatgers tot allò que haguessin de bestreure del seu propi peculi en ocasió del dit viatge. Tal com era de preveure, els genovesos es resistiren a pagar les quantitats a les quals ells mateixos s'havien obligat ${ }^{25}$. Ni tan sols no sabem si ho varen arribar a pagar tot, però el que interessa remarcar és que,

\footnotetext{
${ }^{22} \mathrm{AHCB}, \mathrm{CC}$, Manual, I, fols. 44 r.-45 v. (1325, setembre, 13). Cf. J. MuTGÉ, Contribució a l'estudi, pp. 470-471. Els ciutadans Bernat de Marimon i Burguet de Sarrià foren elegits consellers de la ciutat de Barcelona (Cf. C. BATLle GallarT; M.T. FERRER MALlol; M.C. MAN̂́ MAS; J. MUTGÉ VIVES; S. RIERA VIADDER; M. ROVIRA SOLÃ, El "Llibre del Conséll" de la ciutat de Barcelona. Segle XIV: les eleccions municipals, Barcelona, CSIC, Institució Milà i Fontanals, 2007, docs. 67, 70, 90, 95, 100, 104, 117, 139).

${ }^{23}$ Del VECCHIO, Le rappresaglie, cit., p. 70 i nota 13 , p. 285 doc. I; J. MiRET I SANS, Les represălies, p. 53; R. de MAS LATRIE, Du droit de marque, pp. 47-48.

${ }^{24}$ Tito ANTONI, Il "Lou dels Pizans" del 1303, "Bollettino Storico Pisano", XXXIX (Pisa, 1970), pp. 31-40; IDEM, I "partitari" maiorchini del "Lou dels Pisans" relativi al commercio del pisani nelle Baleari (1304-1322) e (1353-1355), Pisa, Pacini editore, 1977.

${ }^{25}$ Vegeu en el treball repetidament citat (Contribució a l'estudi, pp. 472-477), les peripècies que varen haver de suportar els missatgers barcelonins per entrevistar-se amb els genovesos.
} 
malgrat que la primera intenció del govern municipal de Barcelona havia estat la d'obtenir un dret de marca, la Corona s'inclinà molt aviat a arribar a un acord, a una composició, a fi d'evitar el sempre temut desencadenament de la represàlia. El que sí que és segur és que atacs piràtics com el perpetrat en la coca d'Esteve Bordell varen ser la causa ocasional que donà lloc a la primera guerra declarada entre Barcelona i Gènova (1330-1335). Els constants perjudicis que rebia el comerç de Barcelona decidiren aquesta ciutat a prendre la iniciativa d'organitzar una armada i declarar la guerra pel seu compte, prescindint, fins i tot, en un principi, del sobirà catalanoaragonès, que no $\mathrm{col} \cdot$ laborà fins que la contesa ja s'havia iniciat ${ }^{26}$.

Comentarem ara un altre cas de pirateria, produït, així mateix, en els darrers anys del regnat de Jaume II, en el qual, després de decretada una marca contra els catalans, aquesta no es va arribar a executar, gràcies també a l'activitat diplomàtica i es va resoldre mitjançant un impost. Ens referim a la marca de Bernat Melhac ${ }^{27}$. Bernat Melhac era un mercader francès, oriünd de la vila d'aquest mateix nom, situada al Departament dels Bas Pyrenées. El fet s'esdevingué com segueix: dos vaixells de gran tonatge, anomenats uixers, plens de mercaderies que pertanyien a Bernat Melhac, naufragaren a la costa nord-oest de l'illa de Sardenya, a causa d'una tempesta, i els habitants de l'illa es varen apoderar de tot allò que pogueren. Melhac féu la pertinent reclamació al monarca francès i aquest li va concedir carta de marca contra els catalanoaragonesos ${ }^{28}$. El sinistre tingué lloc en temps de Jaume II, però va ser el seu fill i successor, Alfons el Benigne, qui va desplegar tota la diplomàcia per a evitar la dita marca, ja que aquest darrer sobirà considerava aquesta marca totalment injusta, perquè el naufragi es va produir - com s'ha indicat- a causa d'una tempesta i perquè el rei catalanoaragonès no havia obtingut cap profit de les mercaderies contingudes en els uixers, dels quals, com hem dit, se'n van apoderar els sards, degut a que el naufragi tingué lloc a la costa nordoest de l'illa de Sardenya. Així doncs, amb aquest convenciment, a la tardor de l'any 1329, Alfons el Benigne envià dues ambaixades a París, al seu parent Felip VI de Valois ${ }^{29}$ : la de Ramon de Melany i la de Bernat Cervià. Els ambaixadors catalans intentaren persuadir el rei francès que els motius al-legats per Melhac no eren justos $i$, a més, havia declarat més pèrdues de les que en realitat havia sofert. Però, ni el rei de França ni la seva cort varen atendre les raons invocades pels ambaixadors. Malgrat tot, l'activitat dels

${ }^{26} \mathrm{~J}$. MUTGÉ, El "consell" de Barcelona en la guerra catalanogenovesa durante el reinado de Alfonso el Benigno "Anuario de Estudios Medievales", 2 (1965), pp. 229-256. Reproducido en EADEM, Política, urbanismo y vida ciudadana en la Barcelona del siglo XIV, Barcelona, 2004, pp. 19-46.

${ }^{27}$ Vegeu J. MUTGé, La marca de Bernat Melhac, la Corona catalanoaragonesa $i$ el Llenguadoc (1327-1336), “Anuario de Estudios Medievales”, 16 (1986), pp. 227-238.

${ }^{28} \mathrm{La}$ documentació sobre aquest esdeveniment es troba als registres de cancelleria reial de

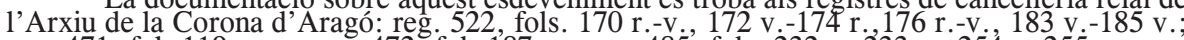
reg. 471 , fol. 119 r.-v.; reg. 472 , fol. 187 v.; reg. 485', fols. 232 v. 233 r., 254 r. -255 r.; reg. 486 , fols. 82 r. -83 r.

${ }^{29}$ Alfons el Benigne i Felip VI de Valois estaven emparentats. El parentiu venia del fet que Isabel, filla de Jaume 1 el Conqueridor i germana de Pere el Gran, es va casar amb Felip III 1'Ardit de França (1270-1285), avi de Felip VI de Valois. 
emissaris no fou en va, ja que, si més no, s’obtingué que, de moment, la marca quedés en suspens, la qual cosa ja era un fet positiu ${ }^{30}$. Tanmateix, mentre tenien lloc les negociacions, els descendents i amics de Bernat Melhac, - perquè Melhac ja havia mort-, sota el pretext de la marca, perjudicaven injustament els súbdits catalanoaragonesos que es trobaven a França, incomplint el pacte mutu establert entre els sobirans francès i catalanoaragonès de respectar, recíprocament, els seus súbdits. Davant d'això, el 26 de novembre de 1331, Alfons el Benigne va demanar a Felip VI de Valois que disposés que algun prohom de la senescalia de Beaucaire fes una investigació per a saber si, deduiit el valor dels vaixells, als quals el rei francès havia generosament renunciat, la suma que es devia als damnificats per la marca ja havia estat cobrada i, en el cas que hagués estat així, els havia d'obligar a rescindir aquest dret de marca, imposant-los silenci perpetu ${ }^{31}$. És evident que els perjudicats encara no havien cobrat, perquè, com veurem unes línies més endavant, molts anys més tard, els descendents de Melhac encara reclamaven la restitució dels danys.

El 1332, Alfons el Benigne encara retrèia al seu parent Felip VI de Valois el fet d'haver concedit, tan injustament, una carta de marca a l'esmentat ja difunt personatge, per la qual s'exigien 10.000 florins d'or, entre el capital, l'interès i les despeses ${ }^{32}$. Mentrestant, i el que interessa subratllar és que, independentment de les negociacions entre les corts francesa i catalanoaragonesa, els mercaders catalans i els descendents d'en Melhac, havien signat l'acord de resoldre la marca pacíficament, comprometent-se a

\footnotetext{
${ }^{30}$ L'ambaixada portada a terme per Ramon de Melany la coneixem bastant bé gràcies a la misiva que Melany va trametre a Alfons el Benigne, la qual es conserva a l'Arxiu de la Corona d'Aragó, publicada per J. MIRET I SANS, Ramón de Melany, embajador de Alfonso IV en la corte de Francia, "Boletín de la Real Academia de Buenas Letras de Barcelona", II (1903-1904), pp. 192-202. Sobre l'ambaixada encomanada a Bernat Cervià, vegeu ACA, C' reg. 522 , fols. 173 v.-174 r. 183 v.-185 v. (J. Mutgé, La marca de Bernat Melhac, pp. 229-231). Ramon de Melany i Bernat Cervià eren ciutadans de Barcelona i fidels consellers d’Alfons el Benigne. De la documentació consultada es dedueix que aquests ambaixadors varen avancar del seu propi peculi els diners necessaris per a realitzar les ambaixades que els foren confiades i la reial cúria els els va restituir després, segons consta a les àpoques o rebuts (Cf. les diferents assignacions econòmiques que se'ls varen fer a J. MUTGÉ, La marca de Bernat Melhac, cit., pp. 237-238).

${ }^{31} \mathrm{ACA}, \mathrm{C}$, reg. 525, fols. 125 v.-126 r. (1331, novembre, 26). Una prova que els francesos continuaven marcant els catalans després de la mort de Bernat'Melhac la tenim en alguns fets que hem constatat a través dels documents: en els darrers mesos de l'any 1330 fou pregonat per ordre del bisbe de Pamiers i del noble Gaston de Foix que tot aquell qui volgués anar a la firra del dit lloc, hi podia concórrer amb tota seguretat. Davant d'això, el mercader Esteve Jaqueti, ciutadà de Barcelona, confiant en la certesa d'allò que s'havia dit en el pregó, va enviar a buscar les mercaderies que tenia a Catalunya i les va fer portar a la dita fira. Durant la celebració d'aquesta Esteve Jaqueti $\mathrm{i}$ altres compatriotes seus foren marcats per Bernat Andreu, servidor d'armes de castellà de Montreale (Alta Garona) i delegat del rei de França i totes les mercaderies que portaven foren venudes en encant públic i no se'ls va fer complement de justícia. Naturalment Esteve Jaqueti va presentar les seves queixes a Alfons el Benigne qui 1'11 de febrer de 1331 s'adreçà als esmentats Gaston de Foix 1 al bisbe de Pamiers i els féu saber que si, en el termini d'un mes, no es restituiia a Jaqueti tot allò que li havia estat pignorat pels oficials del rei de França, dọnaria llicència de marca a l'esmentat Jaqueti (ACA, C, reg. 442, fols. 173 v.-174 v.) Així mateix, hem comprovat que el 20 de novembre de 1331, Alfons el Benigne manifestava al noble Ramon Folc, vescomte de Cardona, que la marca del rẹi de França contra els súbdits de la Corona d'Aragó no havia de ser cap obstacle perquè pogués transitar lliurement. Altrament -afegia el monarca-li desagradaria molt (ACA, C, reg. 525, fol. 48 v.).

${ }^{32}$ ACA, C, reg. 485, fols. 232 v.-233 r (1332, agost, 22). Cf. J. MuTGÉ, La marca de Bernat Melhac, p. 232 .
} 
pagar a aquests darrers una determinada quantitat de numerari, el qual s'obtindria mitjançant l'establiment d'un impost de dos diners per lliura sobre les mercaderies que els catalanoaragonesos introduïssin o traguessin de França. Aquesta decisió fou ben rebuda pels consellers de Barcelona i pels jurats de València i aprovada per Alfons el Benigne, qui autoritzà la instauració de la taxa ${ }^{33}$. Alfons el Benigne - plenament convençut que aquella marca havia estat injustament concedida - va comunicar tot seguit al seu parent, el rei de França, la decisió proposada pels consellers de Barcelona i pels jurats de València de pagar les sumes degudes als perjudicats mitjançant l'establiment d'un impost, tot demanant-li que ho autoritzés. Al mateix temps, li pregava que manés al senescal de Bellcaire (Beaucaire), i als altres oficials reials seus que, sota el pretext de la marca d'en Melhac, no causessin cap dany als catalanoaragonesos ni als seus béns ${ }^{34}$. Tanmateix, els mesos anaven transcorrent i el rei francès no s'ocupava de l'afer de la marca, tot i que Alfons el Benigne s'havia adreçat a ell algunes vegades més, reiterant-li les peticions que ja li havia formulat abans, sobre tot que aprovés l'establiment de la imposició que ell (el rei Benigne) ja havia permès d'instituir ${ }^{35}$. A l'Arxiu Històric de la Ciutat de Barcelona ${ }^{36}$ s'hi conserven uns interessants capítols en els quals es reglamenten totes les qüestions relatives a la percepció de l'impost a la Corona d'Aragó, com també el finançament de les despeses que això comportaria.

Finalment, Felip VI de Valois consentí que l'impost es cobrés en determinades ciutats de França i va renunciar, com havia dit en diverses ocasions, als 3.000 florins d'or que li pertanyien per la marca. Alfons el Benigne aprovà novament tot això el 30 d'abril de 1333 i autoritzà que es pogués introduir qualsevol canvi en els esmentats capítols i, àdhuc, afegir-n'hi de nous, si s'esqueia, i també va permetre que els recaptadors de l'impost el venguessin de la manera que els consellers de Barcelona i els jurats de València decidissin de fer-ho, com efectivament després va esdevenir ${ }^{37}$.

\footnotetext{
${ }^{33} \mathrm{ACA}, \mathrm{C}$, reg, 485, fol. 233 r. (1332, agost, 22). Cf. J. MutgÉ, La marca de Bernat Melhac, p. 232.

${ }^{34}$ ACA, C, reg. 485, fols. 232 v.-233 r. (1332, agost, 22). Cf. J. MuTGÉ, La marca de Bernat Melhac, pp. 232-233.

${ }^{35}$ ACA, C, reg. 485, fols. 254 r.-254 v. (1332, octubre, 28). Cf. J. MutGÉ, La marca de Bernat Melhac, pp. 233-234.

${ }^{36}$ AHCB, CC, Ll. C., 12, fols. 49 v. i ss (1332, novembre, 10). Cf. J. MuTGÉ, La marca de Bernat Melhac, pp. 234-236.

${ }^{37}$ ACA, C, reg. 486, fol. 82 r. (1333, abril, 30). Cf. J. MUTGÉ, La marca de Bernat Melhac, pp. 235. Sembla que els recaptadors de l'impost dels súbdits catalanoaragonesos residents a França, en algunes ocasions, tenien dificultats per a poder fer el pagament als mercaders perjudicats en les dates estipulades. Així doncs, a la primavera de 1334, un d'aquests recaptadors, Bonanat Reig, comunicava als consellers de Barcelona que, amb motiu de les protestes dels mercaders perjudicats, va convenir amb ells de pagar-los 100 lliures la setmana del Ram i la resta per Pasqua i que els mercaders de França consideraven que s'havia de trametre numerari des de Barcelona, per tal que ells es poguessin rescabalar del prestec que havien fet. El 1r d'abril del dit any els consellers lí respongueren que això no els semblava convenient, i que eren els mercaders de Barcelona que comerciaven a Montpeller els qui ho havien de bestreure; si ho feien els de Barcelona en resultarien perjudicats (AHCB, CC, Ll. C., 13, fol. 74 r.)
} 
Arribem a l'any 1335 i la marca de Bernat Melhac encara no estava saldada, perquè la taxa de dos diners per lliura encara no era suficient. Aquesta insuficiència de l'impost era deguda a que els mercaders catalanoaragonesos residents a França no havien estat inclosos en el pagament de la imposició. Per això, el rei Alfons va pregar Felip VI que obligués els mercaders catalans que residien a França a pagar una quantitat equivalent a una cinquena part de les mercaderies comprades o venudes, fins a poder assolir l'esmentada satisfacción ${ }^{38}$.

Com es pot observar, la substitució d'un dret de marca pel pagament d'un impost era un procés extraordinàriament lent. Consta en els documents de cancelleria reial que, en temps de Pere el Cerimoniós, encara subsistia aquest impost per la marca de Bernat Melhac ${ }^{39}$. L'impost s'havia de mantenir en vigor fins que els descendents de Melhac fossin totalment compensats. El cas és que el 7 de novembre de 1345, els damnificats encara no havien estat compensats perquè allò que s'havia recaptat gràcies a l'impost s'havia gastat en els salaris dels recaptadors i en altres despeses innecessàries. Per això, els consellers de Barcelona i els jurats de València consideraren oportú de vendre aquest impost de dos diners per lliura a Deodato de Virencha, jurisperit, veí de Montpeller, sota determinats pactes i per als sis anys propvinents, per tal que, dintre d'aquest temps, s'hagués fet la completa i total satisfacció de les esmentades sumes als descendents d'en Melhac i als altres perjudicats. Pocs dies després, el 18 de novembre, Pere el Cerimoniós confirmà aquesta venda $^{40}$. Aquesta mateixa data, el rei demanava al senescal de Beaucaire, Tolosa i Carcassona, que ajudessin els recaptadors de l'impost, i obliguessin a pagar aquells qui es resistissin a fer-ho ${ }^{41}$.

Hem comentat més amunt els intents que hi havia hagut entre el monarca francès Felip VI de Valois i el català Jaume II per a posar limitacions i pal-liar l'excessiu nombre de marques i contramarques concedides per la cort francesa contra els súbdits de la Corona d'Aragó i de les concedides per la cort del rei catalanoaragonès contra els súbdits francesos ${ }^{42}$. La correspondència intercanviada entre Felip de Valois i Alfons el Benigne durant els mesos d'agost i d'octubre de l'any 1333 posa de manifest que ambdós sobirans es posaren d'acord sobre la manera de procedir en les marques i es varen trametre mútuament cartes patents, sota el títol Super stilo servato in

\footnotetext{
${ }^{38} \mathrm{ACA}, \mathrm{C}$, reg. 471, fols. 119 r.-119 v. (1335, març, 10). Cf. J. MutGÉ, La marca de Bernat Melhac, pp. 236.

${ }^{39}$ Una prova que l'impost encara subsistia la tenim en el fet que a un tal Ramon Forn, qui havia residit primer a Castellfolit de Riubregós (Anoia) i després a la Manresana d'Urgell, li foren confiscats dós cavalls pel castellà de Montreale (Alta Garona), per la qual cosa reclamà a Pere el Cerimoniós. Atenent la seva petició, el 22 d'abril de 1337, el sobirà ordenà a Bonanat Reig i Ramon Castelló, encarregats de recaptar els dos diners per lliura dels súbdits catalanoaragonesos residents a França, que del numerari que arribés a les seves mans compensessin Ramon Forn, però després canvià d'opinió $i$ disposà que no es fes cap nou pagament fins que no estés liquidadà la marca d'en Melhac (ACA, C, reg. 861, fol. 215.1337, abril, 22. Vegeu també J. MIRET I SANS, Les represàlies, cit., p.58).

${ }^{40} \mathrm{ACA}, \mathrm{C}$, reg. 879 , fols. 32 v. -33 r. (1345, novembre, 18$)$.

${ }^{41}$ ACA, C, reg. 635 , fols. 74 v. -75 r. (1345, novembre, 18).

${ }^{42}$ Vegeu notes 5 i 6 .
} 
raubariis $^{43}$. A aquests acords en seguiren uns altres expedits a París el 12 de febrer de 1334, en els quals es confirmaven i entraven de nou en vigor antigues disposicions sobre represàlies entre França i la Corona d'Aragóo ${ }^{44}$. Tanmateix, sembla que aquest acord no fou observat pels senescals de Tolosa, Carcassona i Montpeller; com ho demostra el fet que l'any 1335, els governs de les ciutats de Barcelona i de València varen haver d'enviar emissaris a París per a protestar contra aquells funcionaris que no respectaven el mencionat conveni ${ }^{45}$. Malgrat totes aquestes temptatives, el cert és que no s'havia solucionat gran cosa en la qüestió d'evitar les marques, i la conflictivitat en el mar continuava. Per això, transcorreguts alguns anys, el rei de la Corona d'Aragó, Pere el Cerimoniós, i el monarca francès, Joan II de Valois, poc després d'iniciar-se el regnat d'aquest darrer en el mes d'agost de 1350, decidiren, més aviat que evitar la concessió de marques, buscar la manera més adient de compensar els damnificats ${ }^{46}$.

En aquest sentit, ambdós sobirans designaren una comissió constituïda per un grup de persones eminents de tots dos regnes, a les quals, els seus respectius sobirans concediren plens poders ${ }^{47}$. La tasca que havia de desenvolupar aquesta comissió tenia tres objectius: 1. Fixar una normativa per a l'establiment d'un impost que es cobraria a tots dos regnes, amb la recaptació del qual serien compensats els perjudicats per les pèrdues que havien sofert a causa de les marques; 2. Redactar unes ordinacions que impedissin la comissió de fraus en el pagament de l'impost; i 3 . Avaluar, una per una, totes les persones perjudicades, prenent com a base les declaracions efectuades per elles mateixes $i$, sobre aquestes dades, elaborar una llista d'aquells qui havien de ser rescabalats dels danys, despeses i interessos, com també fixar els imports monetaris que se'ls havien de donar ${ }^{48}$.

En el document redactat pels comissionats resulta evident que s'exigia el pagament d'un impost, com sempre indirecte, és a dir, una taxa aplicada sobre el preu de totes les mercaderies, en general. La comissió fixà una minuciosa normativa per a regular el pagament d'aquesta taxa: totes les mercaderies procedents de la Corona d'Aragó que els súbdits catalanoaragone-

\footnotetext{
${ }^{43}$ ACA, C, reg. 556, fols. 6 v. -7 v. (1333, octubre, 30); fol. 8 r. (1333, novembre, 4).

${ }^{44}$ J. MiRET I SANS, Les represàlies, cit., p. 58.

${ }^{45}$ A. de CApMAnY, Memorias históricas, cit, I, p. 403, ed. a vol.II, pp. 206-210, doc. 137; J. MiRET I SANS, Les represàlies, cit., p. 58

${ }^{46} \mathrm{ACA}, \mathrm{C}$, reg. 556, fols.101 v.-107 r. Cf. l'anàlisi d' aquests acords a J. MUTGÉ, La inseguretat en el Mediterrani Occidental. Acord entre el rei catlanoaragonès Pere el Cerimoniós $i$ el francès Joan II de Valois per a la solució de les marques existents entre ambdós regnes (1351), dins La Corona catalanoaragonesa i el seu entorn mediterrani a la Baixa Edat Mitjana, Barcelona, CSIC, Institució Milà i Fontanals, 2005, pp. 185-203.

${ }^{47}$ Aquestes persones eminents designades foren: per part de França, Pere, bisbe de Cambrai, mestre Ramon de Salgues, Guillem Durand, canonge de la catedral de París, Joan de Levis, senyor de Mirapeix, manescal del rei de França, Arnau de Rocafull. Per part d'Aragó foren designats: Guillem de Bellera, gobernador dels ciomtats del Rosselló i de la Cerdanya, Francesc Roma, doctor en lleis, Tomà de Marçà, cavaller i Jaspert de Tregurà, promotor de la cort reial. Més dades sobre aquestes persones les trobareu a J. MUTGÉ, La inseguretat en el Mediterrani Occidental, cit. pp. 187-189.

${ }^{48}$ ACA, C, reg. 556, fols. 102 r.-v. J. MutGÉ, La inseguretat en el Mediterrani Occidental, cit. pp. 189-190.
} 
sos portessin a França, fos per mar o per terra, haurien de pagar tres diners turonesos per lliura a l'entrada; i per aquelles mercaderies que traguessin del regne de França, haurien de pagar tres diners turonesos més a la sortida. De la mateixa manera, totes les mercaderies que els francesos portarien a la Corona d'Aragó, per mar o per terra, pagarien tres diners a l'entrada i, per les que en traguessin, pagarien tres diners per lliura a la sortida. Així mateix, establiren una rigorosa normativa per a la gestió de l'impost, encaminada també a evitar al màxim que es cometessin fraus i la gabella deixés de pagar$\mathrm{se}^{49}$.

Després d'haver redactat aquesta normativa, la comissió va jurar sobre els Evangelis que compensaria els danys causats per les marques. Es varen fer les citacions pertinents $\mathrm{i}$ foren assenyalats uns dies - tant a França com a la Corona d'Aragó-, en els quals els perjudicats haurien de comparèixer a donar compte de les roberies sofertes, reclamant els danys, despeses i interessos. Després d'haver avaluat tot això, cas per cas, la comissió confeccionà - tal com s'havia compromès a fer-ho - una llista amb els noms de les persones i les quantitats que hom considerava que tenien dret a percebre. Els descendents de Bernat Melhac, tot i que ja havien transcorregut alguns anys, reclamaven les quantitats que encara els eren degudes pel naufragi dels vaixells del dit mercader francès ${ }^{50}$. Tota aquesta normativa, pel que fa a França, fou ratificada a Perpinyà el 23 de desembre de 1351 i, pel que fa a la Corona d'Aragó, es ratificà a Lleida, el 10 d'abril de $1352^{51}$.

\section{INDEMNITZACIÓ PER LA CORONA}

Comentarem ara un altre exemple a través del qual es pot observar que la restitució dels danys soferts per uns mercaders als quals els havien estat preses les mercaderies que portaven en una coca, per tal d'evitar que es posés en pràctica una carta de marca, no es va fer mitjançant el pagament d'un impost sinó que fou la Corona catalanoaragonesa, i més concretament el rei Alfons el Benigne qui, personalment, i no sense dificultats, va assumir el reintegrament dels danys i perjudicis. Aquest conflicte tingué lloc també entre França i la Corona d'Áragó. L'esdeveniment es produí l'any 1325, després de conquerida l'illa de Sardenya per l'infant Alfons, mentre Francesc Carròs, almirall de Jaume II, tenia assetjat el castell de Càller, el comú de Pisa va enviar una gran quantitat de persones i de municions per a ajudar els rebels del castell. Veient-se Carròs en una situació compromesa, va prendre les mercaderies d'uns mercaders de Narbona i de Montpeller, que eren en una

\footnotetext{
${ }^{49}$ Aquesta normativa es troba ben detallada en el document ja citat (ACA, C, reg. 556, fols. 101 v.-107 r.). Vegeu-ne el comentari a J. MUTGÉ, La inseguretat en el Mediterrani Occidental, cit. pp. 190-193.

${ }^{50}$ Ibídem.

${ }^{51}$ ACA, C, reg. 556, fol. 106 v. Cf. J. MutGÉ, La inseguretat en el Mediterrani Occidental, cit. p. 202 .
} 
coca francesa, el patró de la qual era Bernat de Quilhano ${ }^{52}$. Amb motiu d'aquest apressament, el monarca francès llavors regnant, Carles IV el Bell, va decretar una marca a favor d'aquests mercaders de Narbona i de Montpeller i contra la Corona catalanoaragonesa, perquè les mercaderies de les quals Francesc Carròs s'havia apoderat havien estat utilitzades en benefici de la Corona i per defensar el Castell de Càller ${ }^{53}$.

Jaume II no va arribar a un acord amb els mercaders perjudicats per Carròs i va morir sense haver-los indemnitzat. El seu fill i succesor, Alfons el Benigne, tot just al cap d'un mes d'haver començat a regnar, va haver de fer front a aquesta qüestió, perquè el 21 de desembre de 1327, uns representants dels mercaders perjudicats li reclamaren un determinat pagament al-ludint a un pacte establert amb Jaume II. El Benigne, a causa de les despeses motivades per la seva coronació, no podia satisfer-los la quantitat que li demanaven (que no s'especifica en el document), però es va comprometre a fer-la efectiva en el termini de tres anys, a comptar a partir de la immediata solemnitat de Nadal de 1327, pagant una tercera part al final de cada any, tanmateix, els mercaders francesos no varen acceptar aquesta solució $^{54}$. Com en el cas de la marca de Bernat Melhac, Alfons el Benigne es va valer dels ambaixadors Ramon de Melany i Bernat Cerviầ ${ }^{55}$. Mitjançant aquests ambaixadors, Alfons el Benigne féu saber al rei Felip VI de França que les despeses de la seva recent coronació i la guerra contra els sarraïns de Granada, li havien impedit de poder compensar els mercaders pels danys soferts. Li demanava una pròrroga de sis, quatre o tres anys. Les quantitats que els eren degudes els serien pagades bé sobre les rendes de Sardenya, bé sobre altres rendes. Allò que interessava més al sobirà catalanoaragonès era evitar la carta de represàlies com sia molt desconvinent cosa que entre los dits reys aia neguna desamor per marcha ne per altres coses per grans deutes de parantech e bona amistat que són entre ells ${ }^{56}$.

En aquestes circumstàncies, els consellers i els prohomes de Barcelona i altres catalans manifestaren a Alfons el Benigne que, a conseqüència de la marca provocada per Francesc Carròs, ja no podien practicar el comerç en els dominis del rei de França - com sempre ho havien acostumat de fer- i, en canvi, els súbdits francesos podien lliurement negociar a Catalunya. El rei reflexionà sobre aquesta situació i, el 24 de novembre de

${ }^{52} \mathrm{ACA}, \mathrm{C}$, reg. 522 , fols. 183 v.-185 v. Aquesta noticia es troba al fol. 185 r. Vegeu també Jerónimo ZURITA, Anales de la Corona de Aragón, llibre VII, capítol. LXVI (Edició preparada per Angel CANELLAS LÓPEZ, III, Zaragoza, Institución Fernando el Católico, 1978). Cf. J. MUTGE, Una marca francesa contra els catalans, provocada per Francesc Carros (1323-1335), "Homenatge a la Memoria del Prof. Dr. D. Emilio Sáez. Aplec d'estudis dels seus deixebles i col-laboradors", Barcelona, 1989, pp. 127-138). p. 128 .

${ }^{53} \mathrm{ACA}, \mathrm{C}$, reg. 498, fol. 221 v. Cf. J. MUTGÉ, Una marca francesa contra els catalans,

${ }^{54} \mathrm{ACA}$, C, reg. 519 , fols. 33 r.-33 v. (1327, desembre, 21). Cf. J. MutGÉ, Una marca francesa contra els catalans, p.128.

${ }^{55} \mathrm{Cf}$. més amunt, notes 29-30.

${ }^{56}$ ACA, C, reg. 522 fols. 172 v.-173 r ; i fols. 183 v.; 185 v. Cf. J. MutGÉ, Una marca francesa contra els catalans, p.128-129. 
1330 , per tal de compensar les pèrdues sofertes pels catalans per aquest motiu, va expedir una reial provisió en la qual disposava que els mercaders procedents de territoris del rei francès no podien comerciar en terres catalanoaragoneses i, en el termini d'un mes, tenien l'obligació de retirar totes les seves mercaderies, altrament, els serien confiscades. A més, revocava totes les llicències de negociar a la Corona d'Aragó. Manava a tots els oficials reials que pregonessin aquesta reial ordre per tots els indrets de les seves respectives jurisdiccions, per tal que ningú no pogués al·legar que desconeixia la reial ordre. El monarca especificava que aquesta disposició es mantindria vigent durant tot el temps que ell volgués ${ }^{57}$.

Però, el 13 de novembre de 1331, es produí un fet important: s'havia arribat a una avinença entre Alfons el Benigne i els mercaders perjudicats, representats per Berenguer Bonet i Jaume Arquiaire, en nom dels damnificats de Narbona; Salvador d'Antonicis i Joan Calvet, en nom dels damnificats de Montpeller. Tots acudiren a presencia del sobirà a la ciutat d'Alzira (Valencia) i allí, gracies a la intervenció dels nobles Jaume de Xèrica i Ot de Montcada, es va assolir el desitjat acord. El rei francés accedí a concedir la pròrroga que demanava Alfons el Benigne. De la mateixa manera que Alfons el Benigne no dubtava a manifestar que la marca que Felip VI de Valois havia concedit a Bernat Melhac contra els catalanoaragonesos era injusta perque els uixers varen naufragar a causa d'una tempesta i perquè el sobirà catalanoaragonès no havia obtingut cap profit dels vaixells enfonsats, en el cas de la marca concedida amb motiu de l'apressament efectuat per Francesc Carròs, el Benigne es reconeixia deutor de la quantitat de 42.000 lliures barceloneses de tern, ja que les mercaderies foren utilitzades en benefici de la Corona d'Aragó, per això estava disposat a pagar-les dels ingressos de la Corona. Obtinguda, doncs, la pròrroga del rei francès, que li permetia atendre les necessitats de numerari més peremptòries, el 13 de novembre de 1331, Alfons el Benigne es comprometé a fer efectiva l'esmentada quantitat de la següent manera: en pagaria 10.500 lliures cada any en la festivitat de Sant Joan Baptista (24 de juny), durant quatre anys consecutius, fins que quedés completament liquidada la suma. D'aquestes 42.000 lliures barceloneses, 27.791 lliures, 6 sous i 5 diners corresponien als mercaders de Narbona i 14.208 lliures, 3 sous i 7 diners als mercaders de Montpeller. Les diferents liquidacions es farien en el convent dels frares Predicadors de Perpinyà. El rei Alfons es comprometé a complir tot això sota jurament, obligant-hi els seus

${ }^{57} \mathrm{ACA}, \mathrm{C}$, reg. 440, fol. 236 v. (1330, novembre, 24). El cert és que, en aquests anys, catalans i francesos s'escometien mútuament. Per exemple, consta a la documentació que al començament del mes de gener de 1328, alguns catalans varen atacar amb armes a Pere Laurach, Berenguer Bonet i Jaume Arquiaire, mercaders de Narbona, perjudicats per l'acció de Francesc Carròs. El fet s'esdevingué en un camí prop de La Jonquera (Alt Empordà), detingueren les seves famílies i s'apoderaren dels animals que portaven i els conduiren presos a la Torre d'Argent Assabentat del fet, Alfons el Benigne ordenà immediatament a Ramon Guarnall, jutge de Girona, que fes enquesta contra els dits assaltants com també contra els qui s'havien aixecat contra Pere de Santcliment, veguer de Girona i Besalú, quan intentà actuar contra seu (ACA, C, reg. 429, fols. 90 v.-91 r. 1328, gener 17). El rei ordena al batlle de Girona que, de les rendes de la batilla, pagués a l'esmentat jutge Ramon Guarnall la quantitat de vuit sous barcelonesos cada dia pel treball efectuat. 
propis béns. Signaren aquest compromís, al costat del rei, Jaume de Xèrica, Arnau Roger de Pallars, Bernat, vescomte de Cabrera, Ramon Cornell, Gonçal Garcia, Bernat de Boixadors, Felip de Boïl, tresorer reial, Jaume Calvet, vicecanceller i jurista, Bonanat Sapera, notari i tinent dels segells reials i Arnau Ballester, escrivà de ració. Actuaren com a testimonis: Pere de Xèrica, Bernat de Sarrià, Berenguer d'Anglesola, Blai Maça de Vilamerxant, Berenguer de Sentmenat, Jaume d'Arters i Ramon Vall ${ }^{58}$. Alfons el Benigne tingué cura de fer moltes puntualitzacions i de lligar tots els caps per tal d'assegurar l'acompliment del seu compromís. Fins i tot, va demanar al seu fill, l'infant Pere, que es trobava a Saragossa, que confirmés aquesta avinença, la qual li trametia. Li pregava que la volgués refermar llavors i quan arribés a l'edat de catorce anys. Demanava, també, a l'arquebisbe de Saragossa que assumís la responsabilitat que l'infant signés el document, altrament -deia el rei-, en podrien derivar greus danys per als mercaders $\mathrm{i}$ gran deshonor per a ell, ja que s'hi havia obligat sota jurament ${ }^{59}$. Després d'haver subscrit aquest compromís, Alfons el Benigne va haver-se d'ocupar de buscar finançament per a tots els pagaments que havia de fer als mercaders llenguadocians. Els dos fons econòmics als quals el sobirà va recórrer foren la marmessoria de Jaume II i els tributs dels jueus ${ }^{60}$. Com ja hem dit, les liquidacions als esmentats mercaders es feien cada any en la festivitat de Sant Joan Baptista. El rei catalanoaragonès vetllà perquè cap mal pogués esdevenir al seu conseller i escrivà de ració, Arnau Ballester, quan viatgés a Perpinyà per a fer efectius els lliuraments. Per a aquest fi, demanà la col-laboració del lloctinent del rei de Mallorca a la dita ciutat $i$ al mateix rei de Mallorca ${ }^{61}$. I per tal de garantir una major seguretat per a Arnau Ballester en els seus desplaçaments anuals cap a Perpinyà, ordenava al veguer de Barcelona que l'escortés amb una comitiva de genets i d'infants fins a la ciutat de Girona ${ }^{62}$;

\footnotetext{
${ }^{58}$ ACA, C, reg. 498, fols. 221 r.-224 r. (1331, novembre, 13). Cf. J. MutGÉ, Una marca francesa contra els catalans, p.129-131.

${ }^{59}$ ACA, C, reg. 498, fols. 224 r.-225 r. (1331, novembre, 13). Cf. J. MutGÉ, Una marca francesa contra els catalans, p.131.

${ }^{60}$ Vegeu tot el procés i dificultats per a acomplir aquest pacte a J. MUTGÉ, Una marca francesa contra els catalans, pp.131-134. El rei Benigne tingué especial cura perquè no es produís cap alteració. Consta en un document que, en una ocasió, uns mercaders francesos perjudicats per l'acció de Francesc Carròs, sense tenir en compte'les compensacions que la Corona d'Aragó els estava fent, varen pignorar un cert nombre d'animals a uns mercaders catalans, de la Vall d'Aran, anomenats Joan Montaner, Pere Despai, Ramon Deson i d'altres. Aquests presentaren les seves queixes al rei, el qual els va prometre donar-los alguna quantitat de diners en compensació. Per això, el 7 de marc de 1332, Alfons el Benigne s'adreçà al bisbe de Barcelona $i$ als altres diputats designats per a liquidar els deutes de Jaume II $i$ els ordenà que una vegada reintegrats els 100.000 sous que s'havien de pagar als mercaders francesos, en virtut de l'avinença per evitar la marca pel fet de Francesc Carròs, fossin compensats els mercaders de la Vall d'Aran tal com els ho havia promès (ACA, C, reg. 498, fols. 292 v.-293 r.). Es pot observar que, per al rei, el pagament als mercaders francesos era prioritari.

${ }^{61} \mathrm{ACA}, \mathrm{C}$, reg. 498 , fols. 233 r. 235 v.-36 r. (1331, desembre, 11); reg. 500, fol. $236 \mathrm{v}$. (1333, abril, 1); ; reg. 468 , fol. 61 (13334, febrer, 21). En aquests moments, Jaume III de Mallorca tenia 18 anys i estava baix la protecció del consell de regència i sota la tutela del seu oncle Felip, canonge d'Elna. 21).

${ }^{62}$ ACA, C, reg. 498, fol. 235 v. (1331, desembre, 11); reg. 468, fol. 61 v. (1334, febrer,
} 
i, per la seva banda, el veguer de Girona l'havia d'acompanyar des d'aquesta ciutat fins a Perpinya ${ }^{63}$.

Finalment, per acabar, comentarem un exemple que demostra que, malgrat les negociacions no es pogué evitar la concessió i execució d'una carta de represalia. Va ser en l'episodi piràtic que també s'esdevingué en el primer quart del segle $\mathrm{XIV}^{64}$. En aquesta ocasió foren els catalans els qui varen escometre els castellans sense motiu justificat: uns cavallers catalanoaragonesos, per ordre del noble Gispert, vescomte de Castellnou ${ }^{65}$, detingueren l'abat de Jerez, Juan García de Gallegos, fill de Don García Martínez de Gallegos, alcalde major de la ciutat de Sevilla. Quins béns se li robaren a l'abat de Jerez? A l'abat de Jerez no se li robaren bales de llana, ni productes comestibles, sinó el següent: 525 dobles d'or i 3.686 tornesos de plata, dues espases amb ornaments de plata, valorades en 2.500 morabatins de moneda castellana, un anell amb un robí incrustat, que valia 2.200 morabatins, una bossa de seda, dues corretges amb ornaments de plata, valorats en 300 morabatins, un bacinet de plata que valia 100 morabatins, una darga o escut de cuir pintat i segellat amb el seu segell, dues llances, algunes espases i corretges de diferents valors, una sobrevesta folrada, una túnica amb botons de plata i una clàmide o capa.

No cal dir que aquest fet fou considerat com una greu ofensa per part del consell municipal de Sevilla, per la qual cosa, el 7 d'agost de 1319, l'alcalde major, l'algutzir i els prohomes de Sevilla es reuniren a l'església de San Andrés i varen fer comparèixer davant seu els mercaders catalans i mallorquins que es trobaven a la ciutat de Sevilla, protestaren enèrgicament del fet ocorregut i els amenaçaren dient-los que prendrien serioses represàlies sobre les persones i els béns dels catalans si no es feia l'esmena i satisfacció corresponent a l'abat de Jerez. Els primers que pagaren les conseqüències d'aquest succés foren els mercaders catalans que es trobaven negociant a la ciutat de Sevilla, als quals els fou prohibit de treure els béns que tenien a la dita ciutat fins que l'abat de Jerez no recobrés el que se li havia robat. De la documentació consultada es dedueix que aquesta agressió perpetrada en la persona de l'abat de Jerez comportà llargues negociacions, estimació dels béns robats, declaracions del propi abat, valoracions, etc. I va comportar, sense remissió possible, la concessió d'una carta de represàlia contra els mercaders catalans, motiu pel qual molts dels dits comerciants varen ser pignorats i

${ }^{63}$ ACA, C, reg. 498, fol. 235 v. Cf. J. MutGÉ, Una marca francesa, cit., p. 133.

${ }^{64} \mathrm{La}$ descripció d'aquest episodi piràtic es troba a ACA, C, cartes reials de Jaume II, núm. 12.312. La carta està datada un 12 d'agost, però no hi consta l'any. Creiem poder-la situar en el 1319. Vegeu J. MUTGÉ, Activitat piràtica entre catalanoaragonesos $i$ castellans a la Mediterrània occidental durant el regnat de Jaume II, cit., pp. 453-456.

${ }^{65}$ Gispert de Castellnou (1284-1321) fou el darrer vescomte de Castellnou. És interessant de ressenyar que Gispert de Castellnou comanà els estols combinats de Catalunya i Castella a la campanya d'Almeria. Els esmentats estols ocuparen l'Estret, i Ceuta, en poder del rei de Granada, fou atacada i presa el 21 de juliol de 1309. Així mateix, cal esmentar que Gibraltar fou conquerit el 12 de setembre de 1309 , grạccies a l'esforc de Guzmán el Bueno qui comptà amb l'ajut de Gispert de Castellnou i dels mariners catalans (Andrés GIMÉNEZ SOLER, La Corona de Aragón y Granada, Barcelona, 1908. Extret del "Boletín de la Real Academia de Buenas Letras de Barcelona", III i IV. 
marcats a la ciutat de Sevilla ${ }^{66}$. El fet que Juan García de Gallegos formés part de l'estament eclesiàstic motivà que l'agressió de què havia estat objecte trascendís fins a la cort pontifícia. Per altra banda, com que a l'hora d'avaluar els danys ocasionats a l'eclesiàstic, hi havia hagut gran diversitat d'apreciacions, tant per part seva com del seu procurador, Jaume II s'adreçà a l'auditor de la cúria romana per tal que obtingués una declaració jurada del mateix García de Gallegos dels béns que li havien estat robats, a fi que, coneguda la veritat, es pogués actuar amb justícia i se li restituís allò que realment li havia estat confiscat ${ }^{67}$.

La conclusió que podem treure de tot el que hem exposat és que hi va haver molt bona intenció per part dels governs de les nacions de solucionar els danys i perjudicis causats per les marques. S'havien buscat tota mena de solucions, ja fos per via de composició, ja fos mitjançant el pagament d'un impost pels súbdits o, fins i tot, cercant fons entre els ingressos de la Corona. Malgrat totes aquestes temptatives, la inseguretat a la Mediterrània es perllongà encara durant alguns segles.

Data de recepció de l'article: abril 2008.

Data d'acceptació i versió final: setembre 2008.

\footnotetext{
${ }^{66}$ ACA, C, Cartes Reials de Jaume II, núm. 6.219 (1320, juliol, 2). El monarca catalanoaragonès s'adreçava a l'auditor de la cúria papal en els següents termes: "super quadam raubariam que facta extitit Johanni Garsie de Gallegos, abati de Xeres, diocesis Ispalensis, per quosdam milites terre nostre, mandato nobilis vicecomitis Castrinovi, propter quamquidem raubariam pignorati et marchati fuerunt in Ispalensis civitatis aliqui mercatores terre nostre, et de dicta raubaria satisfacere habuerunt..." (Cf. J. MUTGE, Activitat pirätica, cit. , pp. 453-455).

${ }^{67}$ ACA, C, Cartes Reials de Jaume II, núm. 6.219 (1320, juliol, 2). (Cf. J. MutGÉ, Activitat piràtica, cit., p. 455).
} 